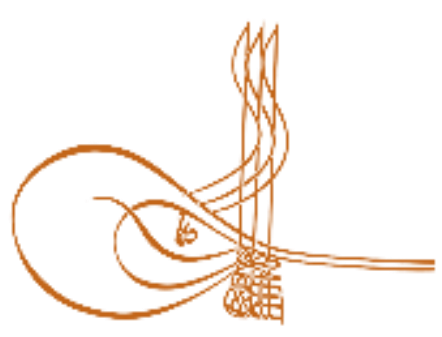

www.turkishstudies.net/social
Turkish Studies - Social Sciences

eISSN: $2667-5617$

Research Article / Araştırma Makalesi

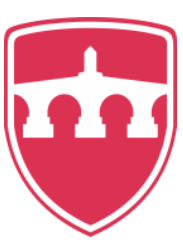

INTERNATIONAL

BALKAN

UNIVERSITY

Sponsored by IBU

\title{
Hırsızlık Suçuna Neden Olan Sosyo-Demografik Değişkenlerin Yıllara Göre Değişiminin İncelenmesi ${ }^{*, * *}$
}

\author{
Investigation of the Change Status of Socio-Demographic Variables That Cause the Theft
}

Aykut Çalışkan $^{* * *}$

\begin{abstract}
Determining the risk levels of crime types by socio-demographic variables is one of the methods commonly used in discriminating criminal events and defining profiles. Data are produced on the basis of socio-demographic variables according to crime types in our country at regional or more micro scale and descriptive results are explained as recommendations. However, Turkey sectional data over a certain time period, there is no specific research area for the detection of changes on the basis of this changing situation. In this articles, it was studied the extent to which the change in the socio -demographic characteristics of individuals who committed the crime of theft, which is among the crimes committed against property in Ankara, has spread over time. The data obtained through surveys conducted between 2014 and 2018 for male detainees and prisoners in penal institutions were reclassified on 6 socio-demographic variables. Subsequently; among the variables obtained from the data acquired in 2014, the socio-demographic variables which were found to be significant were tried to be understood comparatively between 2014 and 2018. In this context; binary logistic regression analysis and correspondence analysis were applied. According to the results obtained in 2014 for the crime of theft; primary and secondary school graduates and being in the 1825 age range were found to be important socio-demographic categories. In the results of the multiple adaptations analysis conducted to explain the changes realized in 2018, it was understood that the results related to the educational level variable remained valid. The significance level of the age range variable could not be determined. It is considered that comparative studies will contribute to understanding the change trends of crimes.
\end{abstract}

\footnotetext{
*Araştırma kapsamında kullanılan ve ikincil veri olarak yararlanılan veriler; araştırmacı tarafindan 2014 ile 2018 yıllarında Ceza ve Tevkifevleri Genel Müdürlüğ̈̈'ne bağlı İnfaz Kurumlarunda gerçekleştirilen tez çalışmalarına ilişkin anketlerin sosyo-demografik değişkenlere ilişkin kısım verilerinin yeniden ele alınmasıyla şekillendirilmiştir. Tez çalıșmalarından farklı olarak literatür, içerik, konu, yöntem ve bulgular boyutlarıyla araștırmanın tasarımı yeniden olușturulmuștur. Araştırma özgün bir çalışma niteliğindedir ve yeniden tasarlanan araştırma modeliyle çalışmanın sistematiği kurgulanmıştır.

** Çalışmanın yayınlanabilmesi için Ceza ve Tevkifevleri Genel Müdürlüğü'ne başvurulmuş, 27/01/2020 tarihinde verilen cevabi yazı doğrultusunda gerekli izin alınmış ve makalenin sonuna eklenmiştir.

**** Dr., Bayburt Emniyet Müdürlüğü, Komiser

PhD, Bayburt Police Department, Inspector (Lieutenant)

ORCID 0000-0002-1886-6991

aykut629aykut@hotmail.com

Cite as/ Atıf: Çalışkan A. (2020). Hırsızlık suçuna neden olan sosyo-demografik değişkenlerin yıllara göre değişiminin incelenmesi, $\quad$ Turkish Studies $\quad$ Social, $\quad 15(3), \quad$ 1017-1032. https://dx.doi.org/10.29228/TurkishStudies.41468

Received/Geliş: 23 January/Ocak 2020

Accepted/Kabul: 25 April/Nisan 2020

Copyright (C) INTAC LTD, Turkey 
Structured Abstract: Crime expresses behaviors that are not legally desired and accepted and targets social life as an object. Every action taken by individuals who commit a crime is among the issues that should be dealt with immediately by the criminal justice system due to the damages in the public sphere. The trial process that develops in the continuation of the crime, on the other hand, determines the material truth from the point of view of the events, and adopts the principle of proportionate punishment of the individuals in the position of perpetrators. The science of criminology, which provides data for the operation of the judicial process of crime, has enabled the production of meaningful data from individuals who have been in the position of perpetrators. For this reason, the descriptive dimensions of crime through socio-demographic variables (age, income level, family structure, etc.) are among the ongoing study topics in the field of criminology.

Deterrence Theory developed by (Becker, 1968:177), he presented a new model by developing the general behavior theory that predicts that crime resulting of rational choices. This model is on the determination of the diversity of the sanctions envisaged in the legal process and the probability of occurrence, by determining which changes applied to crime (Entorf and Spengler; 2000: 75-78). Individuals admitted to crime should be considered like other individuals by evaluating the existing enforcement law regimes and evaluating the rewards (such as money, power) that benefit them if they commit a crime or if they are caught by criminal justice system officials. In other words, the criminal sanctions of the crime are uncertain before the crime is committed by the individuals who commit the crime because the probability of being caught is uncertain.

The individual focuses on post-crime motivating gains as to whether he/she will be caught while committing or after committing a crime in his calculation before committing a crime. The prominent concept is the expected benefit. Even though there are spatial protection measures provided by public institutions or individuals, the main consideration evaluated by individuals who want to carry out the crime is the beneficial context in the context of the results of the event if the individual outweighs the possibility of getting caught and punished (Eide, Rubin \& Shepherd, 2006:3).

This approach, which was groundbreaking and based on approaching crime based on economic thinking, spread with the inclusion of Ehrlich (1973) in empirical studies and subsequently prioritized many studies in particular for countries. Turkey significant variable out of the socio-demographic variables specific to the year in particular has concluded its general, but has not yet been evolving over time efforts to explain the significance of these variables change according to trends. Undoubtedly, the fact that such a study takes time and requires data to be collected over the years affects the technical dimensions of the research and it makes it imperative that the method to be used in the researches is constructed correctly in a scientific way.

In this context, the research was designed on the specific crime type of theft crime by considering these concerns and aimed to determine the trends of change in socio-demographic variables. The frequency distributions of the socio-demographic characteristics of crime are suitable for the discrete variable type; This makes it imperative to analyze with the appropriate scientific methods in determining the changes expected from the temporal point of view. For this reason, the study has adopted itself as the main problem in determining the changes of socio-demographic variables related to theft crime, which is one of the crimes against property, based on the process that varied between 2014 and 2018. In this way the study is designed, the study designed in this way differs from other studies in Turkey.

The data obtained through questionnaires conducted between 2014 and 2018 to male detainees and prisoners in prison institutions were reclassified using 6 socio-demographic variables. Subsequently; the change status of socio-demographic variables, which were found to be significant among these variables obtained from the data obtained in 2014, was tried to be comparatively understood between 2014 and 2018. As the study was conducted over Ankara province, it was seen that crime statistics related to previous years taken as basis in determining the sample.

A re-research has been established using data from socio-demographic variables $\left(\beta_{1}=\right.$ Education Level, $\beta_{2}=$ Marital Status, $\beta_{3}=$ Income Level, $\beta_{4}=$ Family Structure, $\beta_{5}=$ Settlement Status, $\beta_{6}=$ Age) from the study outputs applied to the individual in the case of theft crime systematic. In this respect, the study outputs provide original data according to the first research results. The study was planned by using secondary data analysis technique, which is one of the quantitative research methods. In this respect, the

Turkish Studies - Social, 15(3) 
socio-demographic variables specific to the province of Ankara were revised in 2014 with the sub-categories, and the data of the research conducted in 2018 were subdivided under the same title and the data were made available for analysis. In this way, a new research design was carried out using the secondary data analysis technique.

In this context; binary logistic regression analysis and correspondence analysis were applied. According to the results obtained in 2014, for the theft crime; it has been determined that being a primary and secondary school graduate and being between the ages of 18-25 are important socio-demographic categories. In the results of multiple compliance analysis conducted to explain the change that took place in 2018, it is understood that the results related to the education level variable remain graphically valid; the significance level of the age range variable could not be determined. It is evaluated that comparative studies will contribute to the understanding of the trend of change of crime.

Keywords: Criminology, Socio-demographic variables, Crimes against Property, Ankara, Cross-sectional Data

Öz: Sosyo-demografik değişkenler vasıtasıyla suç türlerinin risk düzeylerinin belirlenmesi, kriminal olayların ayırımında ve profil tanımlanmasında yaygın kullanılan yöntemler arasında yer almaktadır. Bölgesel veya daha mikro ölçekte ülkemiz genelinde de suç türlerine göre sosyo-demografik değişkenler esas alınarak veri üretilmekte ve tavsiye niteliğinde betimsel sonuçlar açıklanmaktadır. Ancak, Türkiye özelinde belirli bir zaman aralığı üzerinden kesitsel veriler esas alınarak bu değişkenlerin değişim durumlarının tespit edilmesine yönelik alan araştırması bulunmamaktadır. Bu çalışma; Ankara ili özelinde malvarlığına karşı işlenen suçlar arasında yer alan hırsızlık suçunu işlemiş bireylerin sosyo-demografik özelliklerine ilişkin değişimin ne ölçüde zamana yayıldığını incelemektedir. Ceza infaz kurumlarında yer alan erkek tutuklu ve mahkûm bireylere 2014 ile 2018 yılları arasında uygulanan anketler vasıtasıyla elde edilen veriler 6 sosyodemografik değişken üzerinden yeniden sınıflandırılmıştır. Devamında; 2014 yılında elde edilen değişkenler arasından anlamlı bulunan sosyo-demografik değişkenler, 2018 yılında tekrar uygulama yapılması suretiyle, söz konusu değişkenlerdeki değişim durumları 2014 ile 2018 yılları arasında karşılaştırmalı olarak anlaşılmaya çalışılmıştır. Bu çerçevede binary lojistik regresyon analizi ile correspondence analizleri uygulanmıştır. 2014 yılında elde edilen sonuçlara göre hırsızlık suçu için; ilkokul ve ortaokul mezunu olma ile 18-25 yaş aralığında olmanın önemli sosyo-demografik kategoriler olduğu tespit edilmiştir. 2018 yılında gerçekleşen değişimi açıklamak amacıyla yapılan çoklu uyum analizi sonuçlarında ise grafiksel açıdan eğitim düzeyi değişkenine ilişkin sonuçların geçerliliğini koruduğu anlaşılırken, yaş aralığı değişkenin önem düzeyi tespit edilememiş̧tir. Karşılaştırmalı olarak yapılan çalışmaların suçların değişim trendlerinin anlaşılmasına katkı sağlayacağı düşünülmektedir.

Anahtar Kelimeler: Kriminoloji, Sosyo-demografik Değişkenler, Malvarlığına Karşı Suçlar, Ankara, Kesitsel Veri

\section{Giriş}

Suç, yasal yönden istenilmeyen ve kabul edilmeyen davranışları ifade etmekte ve nesne olarak toplumsal yaşamı hedef almaktadır. Suç işleyen bireylerin gerçekleştirdiği her eylem, kamusal alanda oluşturduğu zararlar nedeniyle ivedilikle ceza adalet sistemi tarafından ele alınması gereken konular arasında yer almaktadır. Suçun devamında gelişen yargılama süreci ise olayın taraflarını ele alan bakıș açısıyla maddi gerçeği tespit ederek fail konumunda yer alan bireylerin orantılı ceza almalarını prensip edinmektedir. Suça dair adli sürecin işleyişine veri sunan kriminoloji bilimi günümüze kadar fail konumunda yer alan bireylerden anlamlı veriler üretilmesini sağlamıştır. Bundan dolayıdır ki sosyo-demografik değişkenler (yaş, gelir düzeyi, aile yapısı gibi) yoluyla suçun betimleyici boyutları kriminoloji özelinde süregelen çalışma konuları arasında yer almıştır.

(Becker, 1968:177) tarafından geliştirilen caydırıcılık teorisi; suçun rasyonel tercihlerin getirisi sonucu oluştuğunu öngören genel davranış teorisini geliştirerek yeni bir model sunmuştur. Bu model, yasal süreç içerisinde öngörülen yaptırımların çeşitliliğinin ve gerçekleşme olasılığının 
hangi değişimlerden etkilenerek suça başvurulduğunun tespiti üzerinedir (Entorf ve Spengler, 2000: 75-78). Diğer bireyler gibi suça başvuran bireylerin de mevcut infaz hukuku rejimlerini değerlendirerek suç işlemeleri durumunda kendisine fayda sağlayan ödülleri (para, güç gibi) veya ceza adalet sistemi yetkililerince yakalanmaları durumunda alması muhtemel cezalar1 değerlendirerek suça başvurdukları ele alınmaktadır.

Bir başka anlatımla suçun cezai yaptırımları suç işleyen bireyler tarafından suç işlenmeden önce belirsizdir, çünkü yakalanma ihtimali belirsizdir. Birey suç işlemeden önce bir nevi yaptığ 1 hesaplamada suç işlerken veya suç işledikten sonra yakalanıp yakalanmayacağı konusunda suç sonrası motive edici kazançlara odaklanmaktadır. Burada öne çıkan kavram ise beklenen faydadır. Burada her ne kadar mekânsal açıdan kamu kurumları veya bireyler tarafindan sağlanan koruma tedbirleri bulunsa dahi, suç olayını gerçekleştirmek isteyen bireylerin değerlendirdiği temel düşünce, olayın sonuçları bağlamında fayda sağlayan getiridir. Eğer birey yakalanma ve ceza alma ihtimali ağır basıyorsa suça yönelmeyecektir (Eide, Rubin ve Shepherd, 2006:3). Çı̆̆ır açan ve ekonomik düşünceden hareketle suça yaklaşmayı temel edinen bu yaklaşım ampirik çalışmalar konusunda Ehrlich'in (1973) de dahil olmasıyla yayılmış ve devamında ülkeler özelinde pek çok çalışmaya öncelik etmiştir.

Türkiye özelinde sosyo-demografik değişkenler üzerinden anlamlı bulunan değişkenler genel itibariyle yıllara özgü olarak sonuçlandırılmış, ancak gelişen süre zarfında bu değişkenlerin anlamlılık düzeylerine göre değişim trendlerinin açıklanmasına yönelik çalışmalar yapılmamıştır. Şüphesiz böyle bir çalışmanın zaman alması ve yıllara yayılan sürelerle veri toplanılmasını gerektirmesi araştırmanın teknik boyutlarını etkilemekte ve araştırmalarda kullanılacak olan yöntemin de bilimsel açıdan doğru bir şekilde kurgulanmasını zorunluluk haline getirmektedir.

$\mathrm{Bu}$ çerçevede yapılan araştırma söz konusu kaygıları gözeterek spesifik suç türü olan hırsızlık suçu üzerinden tasarlanmış ve sosyo-demografik değişkenlerin değişim trendlerinin tespit edilmesini amaçlamıştır. Suça dair sosyo-demografik özelliklerin frekans dağılımlarının kesikli değişken tipine uygun olması; zamansal açından beklenen değişimlerin tespitinde uygun bilimsel yöntemler ile analiz etmeyi zorunlu hale getirmektedir. Bu nedenle çalışma, 2014 ile 2018 yılları arasında değişen süreci esas alarak malvarlığına karşı suçlar arasında yer alan hırsızlık suçuna dair sosyo-demografik değişkenlerin değişimlerini belirlemeyi kendisine temel problem olarak edinmiştir. $\mathrm{Bu}$ şekilde tasarlanan araştırma, yapılan diğer çalışmalardan Türkiye özelinde farklılaşmaktadır.

Araştırma yönteminde evreni temsil eden örneklemlerin tespiti 2014 ve 2018 yıllarında gerçekleşen araştırmadaki suç istatistikleri kullanılarak yapılmıştır. Bu kapsamda örneklem tespiti çalışmanın ikincil veri olarak kullanıldığı ilk araştırmalardan doğrudan alınmıştır. İlk araştırmalarda yer alan TÜIKK verileri açıklanarak örneklem tespit aşamasının çerçevesi oluşturulmuş, araştırmanın sınırlılıkları detaylı bir şekilde açıklanmıştır.

Kitleyi temsil eden örneklem sayısı, Ankara ilinde gerçekleşen malvarlı̆̆ına karşı suçlar çerçevesinde belirlenmiştir. Bu sebeple araştırmaya katılan birey sayıları belirtilen tarihler arasında farklılık göstermektedir. Çalışma kapsamında 2014 yılı verilerine göre anlamlı olduğu belirlenen sosyo-demografik kategorilerin tespiti yapılmış, devamında 2018 y1lında belirlenen kategorilerin değişim trendleri Binary Lojistik Regresyon Analizi ve Correspondence Analizi ile açıklanmıştır.

\section{Sosyo-Demografik Değişkenler Üzerinden Suçun Yordanması}

Bireyler açısından tanımlayıcı bilgiler içeren ve diğer bireyler arasında tanımlanmasına katk1 sağlayan yaş, cinsiyet, sosyo-ekonomik durum, eğitim düzeyi, medeni durum, aile yapıs1, etnik grup ve dini grup gibi bir takım farklılık arz eden özellikler sosyo-demografik değişkenler olarak adlandırılmaktadır. Son 50 yıllık sürece bakıldığında Becker (1968), tarafından suçlu davranışın sosyo-ekonomik ve demografik değişkenler vasıtasıyla açıklanabileceğini belirtmesinin ardından pek çok kıtada bu konu üzerinde çalışmalar yapılmış, özellikle amprik araştırmaların 
çoğunluğunun Birleşik Devletler ve İngiltere'de gerçekleştirildiği görülmüştür (Buonanno ve Montolio, 2008: 89).

Diğer taraftan son 20 yılda ise Kıta Avrupa'sında suçun açıklanmasına yönelik anılan değişkenler üzerinden çalışmalara önem verildiğini görmekteyiz. Bu çalışmalar malvarlığına karşı işlenen suçlarda anlamlı sonuçlar üretmiştir (Entorf ve Spengler, 2000: 75, Elliott ve Ellingworth, 1998: 527). Amerika Birleşik Devletleri'nde sosyo-ekonomik ve demografik değişkenlerin suç oranları üzerinde etkisinin araştıııldığı, 1960 ile 1998 yılları arasını kapsayan araştırmada; öğrenim düzeyi, işsizlik oranı ve gelir düzeyinin etken olduğu sonucuna ulaşılmıştır (Yorulmaz ve Yakut, 2017: 310).

Türkiye özelinde 1997-2009 yılları arasında gerçekleşen ve mülk suçları olarak tabir edilen malvarlığına karşı işlenen suçların kentleşme, işsizlik ve göç faktörlerinden olumlu yönde etkilendiği tespit edilmiş ve çalışmanın değerlendirilme kısmında ileriki yıllarda yapılan çalışmalarda mülkiyet suçlarının sosyal ve demografik etkilerinin incelenmesi gerektiği belirtilmiş̧ir (Erdoğan vd., 2013: 77). Türkiye geneli bölgeler arası farklılıklar ve bölgeler arasında anlamlı sonuçlar üretilmesini destekleyen mekânsal çalışmalar makro açıdan önemli bakış açıları sunmuş, ancak suçun sosyo-demografik boyutlarının kapsamlı olması ve suçun ekonomik etkilerine dair yaklaşımların kabul görmesi araştırmalara mikro açıdan yönelmeyi zorunluluk haline getirmiştir.

Aynı şekilde geçmişe dönük yapılan çalışmalar incelendiğinde Ankara ve İstanbul illerinde gerçekleşen asayiş ve kaçakçılık suçlarının, diğer illere kıyasla önemli sonuçlar ürettiği tespit edilmiştir (Tüzüntürk, 2009: 81-88). Çok boyutlu ölçekleme analizi sonucu Emniyet Genel Müdürlüğü’nün sunduğu verilerden esinlenerek tespit edilen bulgularda Tüzüntürk (2009), diğer illere nazaran bu illerde olay yoğunluğun daha fazla olduğunu tespit etmiştir. Aytaç ve diğerleri tarafından 2007 yılında Bursa ilinde yapılan çalışmada ise malvarlığına karşı suçların genç yaşlarda ve ekonomik nedenlerden dolayı işlendiği belirlenmiştir (Aytaç vd., 2007: 1).

\section{Araştırmanın Yöntemi}

Çalışmada 2014 ile 2018 yıllarında anket vasıtasıyla toplanan sosyo-demografik verilere ilişkin sonuçların karşılaştırılması planlanmıştır. Bu bakımdan 2014 yılında yapılan araştırmanın anket formunda yer alan sosyo-demografik değişkenler üzerinden çalışma şekillenmiştir. $\mathrm{Bu}$ araştırma, malvarlığına karşı işlenen suçlar özelinde Ankara ilinde gerçekleştirilmiştir. Araştırmada yer verilen suçlar arasında hırsızlık, yağma(gasp), dolandırıcılık gibi suçların yer aldığı görülmüştür.

Bu çalışmada bağımlı değişken hırsızlık suçu ( $Y_{i}=$ Hırsızlık Suçu İşleme Durumu (Evet, Hayır) olarak belirlenmiş, bağımsız değişkenler ise sosyo-demografik değişkenler $\left(\beta_{1}=\right.$ Ĕ̆itim Düzeyi, $\beta_{2}=$ Medeni Durum, $\beta_{3}=$ Gelir Düzeyi, $\beta_{4}=$ Aile Yapısı), $\beta_{5}=$ Yerleşim Durumu, $\beta_{6}=$ Yaş) olarak belirlenmiştir.

Çalışmanın Ankara ili üzerinden yürütülmesi nedeniyle örneklemin belirlenmesinde geçmiş yıllara ilişkin suç istatistiklerinin temel alındığı görülmüştür. Anılan suç türleri üzerinden istatistiksel olarak hesaplanan örneklem sayısı kadar hırsızlık suçu özelinde bireye uygulanan çalışma çıktılarından sosyo-demografik değişkenlere $\left(\beta_{1}=\right.$ Ĕ̈itim Düzeyi, $\beta_{2}=$ Medeni Durum, $\beta_{3}=$ Gelir Düzeyi, $\beta_{4}=$ Aile Yapısı, $\beta_{5}=$ Yerleşim Durumu, $\beta_{6}=$ Yaş) ilişkin veriler ikincil veri olarak kullanılarak yeniden bir araştırma sistematiği kurulmuştur. Bu açıdan yapılan çalışma çıktıları ilk araştırma sonuçlarına göre özgün veriler sunmaktadır.

Çalışma, nicel araştırma yöntemlerinden ikincil veri analizi tekniği kullanılarak planlanmıştır. Bu yöntemle daha önceden yapılan araştırmalarda kullanılan verilerin yeni bir çalışma kapsamında kullanıldığı kabul edilse bile, araştırmacı için yeniden hem veri boyutuyla hem de kullanılan analiz yöntemleri boyutuyla yeni veri sunma durumu söz konusu olmaktadır 
(Neuman, 2014:482). Bu açıdan 2014 yılında Ankara iline özgü sosyo-demografik değiş̧kenler alt kategorileriyle yeniden gözden geçirilmiş ve 2018 yılında yapılan araştırmanın verileriyle alt kategorilerinin aynı başlık altında toplanılması teknik açından sağlanmış ve veriler analize elverişli hale getirilmiştir. $\mathrm{Bu}$ şekilde ikincil veri analiz tekniği kullanılarak yeni bir araştırma tasarımı gerçekleştirilmiştir.

Her iki araştırma kapsamında belirlenen örneklem sayısı tespit şeklinin farklı olması nedeniyle araştırmada yer alan tutuklu ve mahkûmların nasıl belirlendiği yeniden açıklanmıştır. Bu açıdan ilk önce binary lojistik regresyon analiziyle anlamlı değişkenler tespit edilmiş, sonrasında ise verilerin analiz yönteminde 2014 ile 2018 yıllarına ilişkin frekanslara ilişkin gözelerin karşılaştırıldığı correspondence (uyum) analizi uygulanarak değişim trendleri anlaşılmaya çalış1 lmış ve sonuçlar görsel açından yorumlanmaya çalışılmıştır.

Bu kapsamda çalışmada yer alan araştırma soruları aşağıdaki gibi özetlenebilir:

* Hırsızlık suçuna ilişkin anlamlılık içeren sosyo-demografik değişkenler nedir?

* 2014 yılından 2018 yılına kadarki süreçte risklerin değişim trendleri nelerdir? sıralanmıştır:

Bahse konu araştırma sorularına cevap aramak amacıyla oluşturulan hipotezler ise aşağıda

$$
\begin{aligned}
& \beta_{1=} \beta_{2=} \beta_{3=} \beta_{4=} \beta_{5=} \beta_{6=} 0 \\
& \beta_{i,(2014)=} \beta_{i ;(2018) ;} i=1,2, . ., 6
\end{aligned}
$$

\subsection{Veri Toplama Araçları}

2014 ve 2018 olmak üzere önceden yapılan her iki çalışma da, Ankara ilinde bulunan 2 nolu L tipi kapalı infaz kurumunda yer alan erkek tutuklu veya mahkûmlara uygulanmıştır. Bu açıdan 2014 yılındaki çalışmada yer verilen sosyo-demografik değişkenler kategorik olarak 2018 yılında yapılan çalışmaya uyarlanmıştır. Böylelikle çalışma karşılaştırmalı olarak farklılıkları görebilmeye elverişli hale gelmiştir.

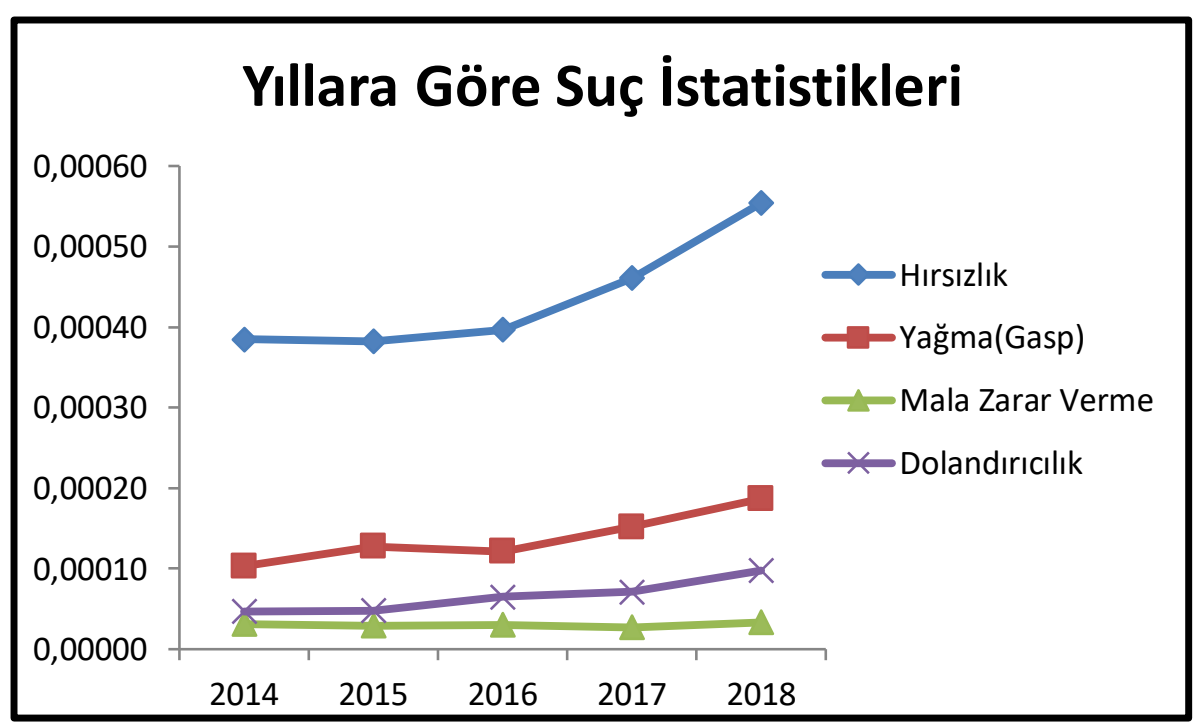

Şekil 1: Türk Toplumunun Malvarlığına Karşı Suçlar Özelinde Suç İstatistikleri Kaynakça: TÜİK, 2020:Adalet ve Nüfus İstatistikleri

Ayrıca 2014 ve 2018 yıllarında yapılan araştırmada örneklem seçme yöntemini açıklamadan önce anılan suçlarda artış trendi de günümüz verileri üzerinden sunulmuştur. Bununla beraber 2018 yılında nüfus açısından artış görülmesiyle birlikte, suç oranlarında artış ise hırsızlık ve yağma (gasp) suçlarında dikkat çekicidir. Hırsızlık suçu 2014 yılında yüz binde 4 iken, 2018 
yılında yüz binde 6 oranına çıkmıştır. Elde edilen bu sonuç; çalışmanın hırsızlık suçu üzerine yapılmasının gerekçesi olarak gösterilebilir.

Araştırmanın örnekleme metodu, basit tesadüfi örneklemedir. Bu açıdan örneklemin; en az örneklem sayısı kadar erkek mahkûmlardan oluşması, yaş dağılımı bakımından 18 ile 65 yaş arasında dağılması gerektiği tespit edilmiştir. 2018 yılında yapılan çalışmadan elde edilen verilerin öncekiyle karşılaştırılması amaçlandığından örneklem seçiminde aynı özellikleri taşıyan bireylerin seçilmesine dikkat edilmiştir.

\subsubsection{Yılında Yapılan Araştırmada Veri Toplama Süreci}

Araştırma kapsamında ilk olarak 2014 yılındaki örneklemin tespit edilmesinde TÜIKK üzerinde o yıllar için var olan 2006-2008 yıllarına ilişkin veriler kullanıldığı tespit edilmiştir. Bu çerçevede 2006-2008 yılları arasında malvarlığına karşı işlenen suçların (yapılan çalışmada hırsızlık, yağma (gasp), mala zarar verme ve dolandırıcılık gibi suçları barındırmaktadır) diğer suçlar arasında yaklaşık olarak \%26'lık bir orana sahip olduğu tespit edilmiştir. Ortalama olarak Ankara ilinde her yıl 1900 kişinin bu suçlardan infaz kurumlarına girmesinden dolayı \% 95 güven aralığında tüm malvarlığına karşı suçlar arasından Ankara ilini temsil edebilecek örneklem sayısı 75 birey olarak belirlenmiştir. Çalışma 113 tutuklu ve mahkûm üzerinden şekillenmiştir. Örneklemde hırsızlık suçuna karıştığını ifade edenlerin sayısı 43 kişi olarak tespit edilmiştir.

Tablo 1: 2014 yılı araştırması için suçlu davranış değişkenine ait betimleyici istatistikler

\begin{tabular}{ccccc}
\hline İşlenen Suç & Hayır & Evet & Kayıp Veri & Toplam \\
Hırsızlık & 69 & 43 & 1 & 113 \\
\hline
\end{tabular}

Çalışmaya katılan tutuklu veya mahkûmların işlediğini beyan ettiği suçlara ilişkin betimleyici istatistiklere göre hırsızlık suçunun 43 kişi tarafından işlendiği tespit edilmiştir.

\subsubsection{Yılında Yapılan Araştırmada Veri Toplama Süreci}

2014 yılından sonra 2018 yılında gerçekleştirilen ikinci araştırmanın örnekleminin tespit edilmesinde TÜİK verileri üzerinden 2013 ile 2016 yıllarına ilişkin mala zarar verme suçuna ilişkin veriler kullanılmıştır. Bu çalışma daha özel bir suç türü olan mala zarar verme suçu özelinde şekillendiği için örneklem tespiti mala zarar verme suçu üzerinden şekillenmiştir. Ancak, ikinci araştırmanın anket kısmında diğer suçlara da yer verildiği görülmüş ve bu suçlar arasında hırsızlık suçunun da olduğu belirlenmiştir.

$\mathrm{Bu}$ çerçevede mala zarar verme suçunun diğer suçlar arasında yaklaşık olarak binde 12'lik bir orana sahip olduğu tespit edilmiştir. Ortalama olarak Türkiye'de her yıl 2.677 kişinin bu suçtan infaz kurumlarına girmesinden dolayı çalışmanın örneklemi \% 95 güven aralığı düzeyinde 65 birey olarak belirlenmiştir.

İkinci çalışmanın gerçekleştiği illerden biri olan Ankara'nın diğer iller olarak belirlenen İstanbul ve İzmir'e göre nüfus açısından yapılan kıyaslama sonrası örneklem sayısı 27 birey olarak belirlenmiştir. Bu kapsamda 24 erkek 16 kadın olmak üzere toplam 40 bireyin katılımıyla çalışma sonuçlandırılmış, ancak 2014 yılında elde edilen verilerle kıyaslama yapılabilmesi için sadece erkek bireylerin özelliklerine yer verilmiştir. Aşağıdaki tablo incelendiğinde 24 erkek bireyin 18'inin hırsızlık suçuna karıştığı anlaşılmıştır.

Tablo 2: 2018 yılı araştırması için suçlu davranış değişkenine ait betimleyici istatistikler

\begin{tabular}{ccccc}
\hline İşlenen Suç & Hayır & Evet & Kayıp Veri & Toplam \\
Hırsızlık & 6 & 18 & 0 & 24 \\
\hline
\end{tabular}

www.turkishstudies.net/social 
Çalışmaya katılan tutuklu veya mahkûmların işlediğini beyan ettiği suçlara ilişkin betimleyici istatistikler yukarıdaki tabloda gösterilmiştir. Malvarlığına karşı suçlar arasında hırsızlık suçunun 18 kişi tarafından işlendiği anlaşılmıştır.

\subsection{Veri Değerlendirme Süreci}

Araştırma kapsamında bağımsız değişken olarak tespit edilen sosyo-demografik değişkenlere ilişkin kategoriler her iki dönemde elde edilen verilerin kategorik olarak benzer hale getirilmesinin ardından analize sürecine geçilmiştir. İlk olarak, 2014 y1lı verileri üzerinden bağımsız değişkenin üç veya daha fazla isimsel kategori içermesi ve bağımsız değişkenlerin risk olarak rollerinin tespit edilebilmesi amaciyla IBM SPSS Statistics 23 adlı paket programda lojistik regresyon analizi uygulanmıştır. Bu çerçevede hırsızlık suçunu işlediğini ve işlemediğini belirten bireylerin sosyo-demografik özellikleri yönüyle bütüncül açıdan değerlendirilmesi sağlanarak, hırsızlık suçunu işlemiş bireylerde hangi bağımsız değişkenlerin ön plana çıktığı saptanmıştır.

Devamında sadece hırsızlık suçunu işlemiş bireylerden etken olduğu tespit edilen 2014 yılına ait risklerin 2018 yılında değişim sürecinin belirlenebilmesi amacıyla, aynı paket programda uyum analizi olarak kabul edilen multiple correspondence analizi uygulanmıştır. Correspondence analizi; kategorik verilerin sira ve sütun olarak birlikte değişimlerinin grafiksel bir uzayda gösterilmesini amaçlayan çok değişkenli analiz yöntemi olarak kabul edilmektedir. Bu analiz yöntemi; tablo gözlerinin ki-kare değerlerinden veya değişkenlerin kategorileri arasındaki Öklid uzaklıklarından istifade ederek hesaplanan farklılıklar yardımıyla gösterilen bir grafiksel metod olarak da tabir edilmektedir (Özdamar, 2010: 445).

\subsection{Araştırmanın Sınırlılıkları}

Yapılan araştırmada ikincil veri tekniği kullanması nedeniyle ilk araştırmada sunulan örneklem tespit yöntemi kullanılmış ve bu sonuçlara bağlı kalınmıştır. 2020 yılında TÜİK tarafından sunulan ve yukarıda Şekil.1'de gösterilen sonuçlara göre hırsızlık suçunun artış gösterdiği tespit edilmiştir. Ancak araştırma kapsamında kitleyi temsil eden örneklem sayılarının yukarı yönlü değişkenlik göstermediği açık bir şekilde görülmektedir. 2018 yılında sunulan örneklem sayısı 2014 yılında sunulan örneklem sayısına göre daha azdır.

Öte yandan bilimsel araştırmalarda etik kaygının her zaman ön planda tutulması gerektiği bilincinden hareketle, yapılan bu araştırmanın ikincil veri tekniği olarak planlanması ve mecburen benzer özellikler taşıması gereken ilk verilere bağlı kalması nedeniyle açıklama yapılması bir zorunluluk olarak görülmüştür.

Çalışma kapsamında yer alan 2014 ile 2018 yıllarına ilişkin sonuçlar bu çalışma özelinde indirgendiği için ve benzer boyutları içeren bir araştırma yapılmasından dolayı örneklem sayısında azalma olmuştur. $\mathrm{Bu}$ nedenle 2018 yılında çalışmaya katılan kadınlara ilişkin veriler kullanılamamıştır. Çalışmanın sunmuş olduğu sosyo-demografik kategorilerin değişim durumları böylelikle analize elverişli hale getirilmiştir.

\section{Araştırmanın Bulguları}

Araştırma kapsamında önerilen hipotezler ve bağımsız değişkenlere ilişkin frekans dağılımları IBM SPSS Statistics 23 adlı paket programda yapılan analiz çıktılarıyla birlikte paylaşılmıştır. Çalışmada 2014 y1lı verileri üzerinden mevcut durum ortaya konulmuş ve etken olduğu tespit edilen değişkenler ortaya çıkarılmış, akabinde risk içeren bağımsız değişkenlerin 2014 yılı ile 2018 yılı arasındaki birlikte değişimlerini içeren grafiksel gösterimleri paylaşılmıştır. 


\subsection{4 yılı verilerine göre Bağımlı ve Bağımsız Değişkenlerinin Frekans Dağılımları}

Bağımlı değişken olarak belirlenen hırsızlık suçu ve sosyo-demografik değişkenler $\left(\beta_{1}=\right.$ Eğitim Düzeyi, $\beta_{2}=$ Medeni Durumu, $\beta_{3}=$ Gelir Düzeyi, $\beta_{4}=$ Aile Yapısı, $\beta_{5}=$ Yerleşim Durumu, $\beta_{6}=$ Yaş) olarak belirlenen bağımsız değişkenlerin frekans dağılımları aşağıda ifade edilmiştir.

Tablo 3: Değişkenlerin Frekans Dağılımları

\begin{tabular}{|c|c|c|c|c|c|c|c|}
\hline \multirow{2}{*}{$\begin{array}{l}\text { Bağımsız } \\
\text { Değişsenler }\end{array}$} & \multirow{2}{*}{ Kategoriler } & \multirow{2}{*}{ Frekans } & \multicolumn{5}{|c|}{ Parametre Kodları } \\
\hline & & & 1 & 2 & 3 & 4 & 5 \\
\hline \multirow{6}{*}{ Eğitim Durumu } & Okuma Yazma Bilmiyor & 1 & 1 & 0 & 0 & 0 & 0 \\
\hline & Okuma Yazma Biliyor & 5 & 0 & 1 & 0 & 0 & 0 \\
\hline & İlkokul & 12 & 0 & 0 & 1 & 0 & 0 \\
\hline & Ortaokul & 21 & 0 & 0 & 0 & 1 & 0 \\
\hline & Lise & 26 & 0 & 0 & 0 & 0 & 1 \\
\hline & Ön lisans ve üstü & 17 & 0 & 0 & 0 & 0 & 0 \\
\hline \multirow{4}{*}{$\begin{array}{l}\text { Kategorize } \\
\text { Edilmmiş Yaş } \\
\text { Aralığı }\end{array}$} & 18-25 Yaş Aralığı & 16 & 1 & 0 & 0 & & \\
\hline & 26-33 Yaş Aralığı & 33 & 0 & 1 & 0 & & \\
\hline & 34-41 Yaş Aralığı & 21 & 0 & 0 & 1 & & \\
\hline & 42 ve Üstü Yaş Aralığı & 12 & 0 & 0 & 0 & & \\
\hline \multirow{3}{*}{ Medeni Durumu } & Evli & 40 & 1 & 0 & & & \\
\hline & Bekâr & 37 & 0 & 1 & & & \\
\hline & $\begin{array}{l}\text { Diğer(Ayrı Yaşama-Dul- } \\
\text { Boşanmış) }\end{array}$ & 5 & 0 & 0 & & & \\
\hline \multirow{3}{*}{ Gelir Düzeyi } & 2000 TL ve aşağıSı & 62 & 1 & 0 & & & \\
\hline & 2001 TL- 3000 TL aras 1 & 8 & 0 & 1 & & & \\
\hline & 3001 TL ve yukarısı & 12 & 0 & 0 & & & \\
\hline \multirow{2}{*}{ Yerleşim Durumu } & Göçle Gelmiş & 31 & 1 & & & & \\
\hline & Yerli & 51 & 0 & & & & \\
\hline \multirow{2}{*}{ Aile Yapısı } & Çekirdek Aile & 63 & 1 & & & & \\
\hline & Geniş Aile & 19 & 0 & & & & \\
\hline
\end{tabular}

Bağımlı değişken olarak araştırmanın konumlandırıldığı hırsızlık suçunu işlediğini belirten 43 tutuklu ve mahkûm bulunmaktadır. 2014 yılında çalışmaya katılan katılımcılardan eğitim düzeylerine ilişkin kategoriler arasında en çok lise mezunu (26) olan bireylerin yer aldığ görülmektedir. Lise mezunu tutuklu ve mahkûmları takiben ortaokul (21), ön lisans ve üstü (17) ile ilkokul mezunları (12) gelmektedir. Okuma yazma bilmediğini belirten 1 kişi bulunmaktadır.

Medeni durum değişkenine ilişkin veriler incelendiğinde; ilk sırada evli olduğunu belirten bireyler (40) yer almakta olup, devamında bekâr (37) ve diğer kategorisi altında tek başına veya ayrı yaşadıklarını belirten bireyler (5) gelmektedir. Gelir durumları incelendiği zaman çoğunluğunun $(62 ; 0,76) 2.000$ lira aşağısında gelir durumlarının olduğu anlaşılmaktadır.

Çekirdek aile içerisinde yaşadıklarını belirten tutuklu ve mahkûmların sayısı $(63 ; 0,77)$ olarak tespit edilmiştir. Geniş ailede yaşadıklarını belirten birey sayısı ise çekirdek ailede yaşadığını belirten katılımcı sayısına göre daha azdır $(19 ; 0,23)$. Çalışmada yer alan katılımcıların 
yerleşim durumları incelendiği zaman; yerli (51) olduğunu belirten katılımcı sayısının, göçle (31) geldiğini belirten katılımcı sayısına göre daha fazla olduğu görülmektedir. Yaş aralığının en çok; 26-33 (33;0,40) olduğu görülmektedir. 26-33 yaş aralığını takiben 34-41 yaş aralığı $(21 ; 0,26)$ gelmektedir. Araştırma kapsamında yer alan bireylerin yaş aralığı olarak en düşük kategorinin yer aldığ 12 yaş ve üstünde yer alan birey sayısı ise 12 olarak tespit edilmiştir.

Çalışmada yer alan bireylerin bağımsız değişkenler boyutuyla öne çıkan özellikleri değerlendirildiğinde; lise ve ortaokul mezunu, 2.000 lira aşağısında gelire sahip, çekirdek aile içinde yaşayan, yerli, 26-33 yaş aralığında bulunan bireylerin ön plana çıktığı görülmektedir. Diğer bağımsız değişken olan medeni duruma bakıldığında evli ve bekâr bireylerin benzer dağıldıkları görülmüştür.

\subsubsection{Yılı Verilerine Göre Etken (Risk) Olan Bağımsız Değişkenler}

$\mathrm{Bu}$ kısımda hırsızlık suçunun işlenmesine etken olduğu değerlendirilen sosyo-demografik değişkenlerin ( $\beta_{1}=$ Eğitim Düzeyi, $\beta_{2}=$ Medeni Durumu, $\beta_{3}=$ Gelir Düzeyi, $\beta_{4}=$ Aile Yapıst, $\beta_{5}=$ Yerleşim Durumu, $\beta_{6}=$ Yaş) önemlilik düzeyleri tespit edilmiştir. Öncelikle araştırmada kullanılan lojistik regresyon analizinin model uyum testi analiz edilmiştir.

Tablo 4: Model Uyum Testi

\begin{tabular}{ccc}
\hline $\begin{array}{c}-2 \\
\text { Loglikelihood }\end{array}$ & $\begin{array}{c}\text { Cox\&Snell R } \\
\text { Square }\end{array}$ & $\begin{array}{c}\text { Nagelkerke } \\
\text { R Square }\end{array}$ \\
\hline $\mathbf{7 3 , 5 1 1}$ &, 357 &, 484 \\
\hline
\end{tabular}

Lojistik regresyon analizinde uygulanılan modelde etken (risk) olduğu değerlendirilen bağımsız değişkenlerin tespit edilebilmesine yönelik aşamaya geçilebilmesi için modelin gücü değerlendirilmiştir. Ayrıca modelin açıklama gücünü gösteren ve uyum iyiliği ölçülerinin yorumlanması amacıyla geliştirilen Pseudo $\mathrm{R}^{2}$ değeri ise (Negelkerke;0, 484 0,5) olarak tespit edilmiştir. Modelin açılama gücünün orta düzeyde olduğu ifade edilebilir.

Lojistik regresyon modelinin uygulanmasının ardından modelde yer alan bağımsız değişkenlerin önem düzeylerinin gösterildiği test sonuçlarına yer verilmiş, devamında ise bağımsız değişkenlere ilişkin parametre tahmin sonuçları açıklanmıştır. Böylelikle etken olduğu belirlenen bağımsız değişkenlerin tespiti yapılabilmiştir.

Tablo 5: Modelin Sinıflandirma Oranı

\begin{tabular}{llccc}
\hline \multirow{2}{*}{ Sinıflandırma } & \multicolumn{2}{c}{ Hırsızlık } & \multicolumn{1}{c}{$\begin{array}{c}\text { Doğru } \\
\text { Yürde }\end{array}$} \\
\cline { 3 - 3 } Hırsızlık & Hayır & 44 & Evet & \\
& Evet & 8 & 6 & 88,0 \\
& Toplam Yüzde & & 75,0 \\
& & & 82,9 \\
\hline
\end{tabular}

Modelin sınıflandırma ölçütünde \%82,9 oranında doğru sınıflandırma yapılabilmiştir. Anlamlı bulunan kategorilerinin test edilmesi ve bağımlı değişken olarak belirlen hırsızlık suçunu işleme durumunu ( 0 =Hayır, $1=$ Evet $)$ değerlendirilmesi amacıyla yapılan analiz sonuçları aşağıda paylaşı1mıştır. 


\begin{tabular}{lccccc}
\hline \multicolumn{5}{c}{ Tablo 6: Bağımsız Değisskenlere Ait Kategorilerin Önem Düzeyleri } \\
\hline Değişkenler & Katsayı & $\begin{array}{c}\text { Wald } \\
\text { İstatistiği }\end{array}$ & $\begin{array}{c}\text { Serbestlik } \\
\text { Derecesi }\end{array}$ & $\begin{array}{c}\text { Belirleyici } \\
\text { Değer }\end{array}$ & Risk Katsayısı \\
\hline Eğitim durumu & & 7,081 & 5 & 0,21 & \\
Eğitim durumu(1) & 45,760 &, 000 & 1 & 1,00 & $7,46861 \mathrm{E}+19$ \\
Eğitim durumu(2) & 2,082 & 1,601 & 1 & 0,21 & 8,02 \\
Eğitim durumu(3) & 2,870 & 4,752 & 1 & $\mathbf{0 , 0 3} *$ & 17,64 \\
Eğitim durumu(4) & 2,148 & 3,745 & 1 & $\mathbf{0 , 0 5 * * *}$ & 8,57 \\
Eğitim durumu(5) &, 974 &, 822 & 1 & 0,36 & 2,65 \\
Medeni durum & & 2,256 & 2 & 0,32 & \\
Medeni durum(1) & $-2,260$ & 2,109 & 1 & 0,15 & 0,10 \\
Medeni durum(2) & $-1,799$ & 1,318 & 1 & 0,25 & 0,17 \\
Ekonomik düzeyi & &, 115 & 2 & 0,94 & \\
Ekonomik düzeyi(1) & 21,683 &, 000 & 1 & 1,00 & 2610418468,97 \\
Ekonomik düzeyi(2) & 22,054 &, 000 & 1 & 1,00 & 3784145604,44 \\
Aile özelliği(1) &, 233 &, 101 & 1 & 0,75 & 1,26 \\
Yerleşim(1) &,- 731 & 1,419 & 1 & 0,23 & 0,48 \\
Yas kategorik & & 7,687 & 3 & 0,05 & \\
Yas kategorik(1) & 2,684 & 5,106 & 1 & $\mathbf{0 , 0 2 * * *}$ & 14,64 \\
Yas kategorik(2) & 1,033 & 1,075 & 1 & 0,30 & 2,81 \\
Yas kategorik(3) &,- 030 &, 001 & 1 & 0,98 & 0,97 \\
Sabit Değer & $-22,500$ &, 000 & 1 & 1,00 & 0,00 \\
\hline Eğitron
\end{tabular}

$\overline{(\text { Eğitim durumu(3)=亡̈lkokul, Eğitim durumu(4)=Ortaokul, Yas kategorik(1)=18-25 Yaş Aralığı) }}$

Hırsızlık suçu özelinde suç işleme durumu olarak 1 yanıtı, yani evet cevabını veren tutuklu ve mahkûm bireyler arasından; $\left\{\beta_{1,3}=\right.$ İlkokul, $\beta_{1,4}=$ Ortaokul, $\beta_{6,1}=18,25$ yaş aralığ $\}$ değişkeni önemli bulunmuştur $(*, * *, * * *<=\mathrm{p}=0,05)$. Analiz sonuçları anlamlı çıkan sonuçlar açısından değerlendirildiğinde ilkokul düzeyinde eğitim düzeyine sahip olanların hırsızlık suçunu işleme riski; 17,6 kat artarken, ortaokul düzeyinde eğitim durumuna sahip bireylerin ise hırsızlık suçunu işleme riski ise 8,5 kat artmaktadır.

Diğer taraftan; 18-25 yaş aralığında bulunanların ise hırsızlık suçunu işleme riski 14,6 kat artmaktadır. Bu sayede analiz sonuçları kapsamında anlamlılık teşkil eden kategorilerin önem düzeyleri de açıklanmıştır.

\subsubsection{4-2018 Yılları Arasında Değişim Trendinin Grafiksel Gösterimi}

Bu kısımda 2014 ile 2018 yılları arasında hırsızlık suçuna karıştığını beyan eden tutuklu ve mahkûmların eğitim durumu ve yaş aralığı değişkenleri üzerinden değişim trendi grafiksel açıdan açıklanmaya çalışılmıştır. Öncelikle 2014 yılında suça karışan bireylerden önem arz ederek etken olduğu belirlenen eğitim durumu ve yaş aralığ değişkenleri lojistik regresyon analiziyle tespit edilmiş, özellikle risk düzeyleri tespit edilen kategorilerin bu iki değişken altında yer aldığ 1 görülmüştür. 
Tablo 7: Bağımsız Değișkenlere Ait Kategorilerin Koordinatları

\begin{tabular}{|c|c|c|c|c|}
\hline \multirow{3}{*}{$\begin{array}{c}\text { Sosyo- } \\
\text { demografik } \\
\text { Değişkenler }\end{array}$} & \multirow{3}{*}{ Kategoriler } & \multirow{3}{*}{$\begin{array}{c}\text { Ağırlıklandırılmış } \\
\text { Frekans }\end{array}$} & \multirow{2}{*}{\multicolumn{2}{|c|}{$\begin{array}{c}\begin{array}{c}\text { Merkezi } \\
\text { Koordinatlar }\end{array} \\
\text { Boyutlar }\end{array}$}} \\
\hline & & & & \\
\hline & & & 1 & 2 \\
\hline \multirow[t]{6}{*}{ Eğitim Düzeyi } & $\begin{array}{l}\text { Okuma Yazma } \\
\text { Bilmiyor }\end{array}$ & 12 & 1,458 &,- 006 \\
\hline & $\begin{array}{l}\text { Okuma Yazma } \\
\text { Biliyor }\end{array}$ & 12 &,- 939 & $-2,010$ \\
\hline & İlkokul & 12 & ,919 &,- 171 \\
\hline & Ortaokul & 12 &, 133 &, 351 \\
\hline & Lise & 12 & $-1,455$ & 1,163 \\
\hline & Ön lisans ve üstü & 12 &,- 116 &, 673 \\
\hline \multirow[t]{4}{*}{ Yaş Aralığg } & 18-25 Yaş Aralığ & 18 &,- 001 &,- 002 \\
\hline & 26-33 Yaş Aralığı & 18 & ,000 &,- 002 \\
\hline & 34-41 Yaş Aralığ1 & 18 &, 000 &, 005 \\
\hline & $\begin{array}{l}42 \text { ve Üstü Yaş } \\
\text { Aralığ } 1\end{array}$ & 18 & ,000 &,- 001 \\
\hline \multirow{2}{*}{$\begin{array}{l}\text { Suç İşleme } \\
\text { Durumu }\end{array}$} & Evet & 24 & ,000 & ,000 \\
\hline & Hayır & 48 & ,000 &, 000 \\
\hline
\end{tabular}

Bu bağlamda 2014 yılında Ankara ilinde tutuklu ve mahkûmlardan elde edilen veriler vasıtasıyla hırsızlık suçuna karıştığını beyan eden veya etmeyen bireylerin eğitim düzeyi ve yaş değişkenleri üzerinden uyum durumu aşağıda grafiksel açıdan gösterilmiştir.

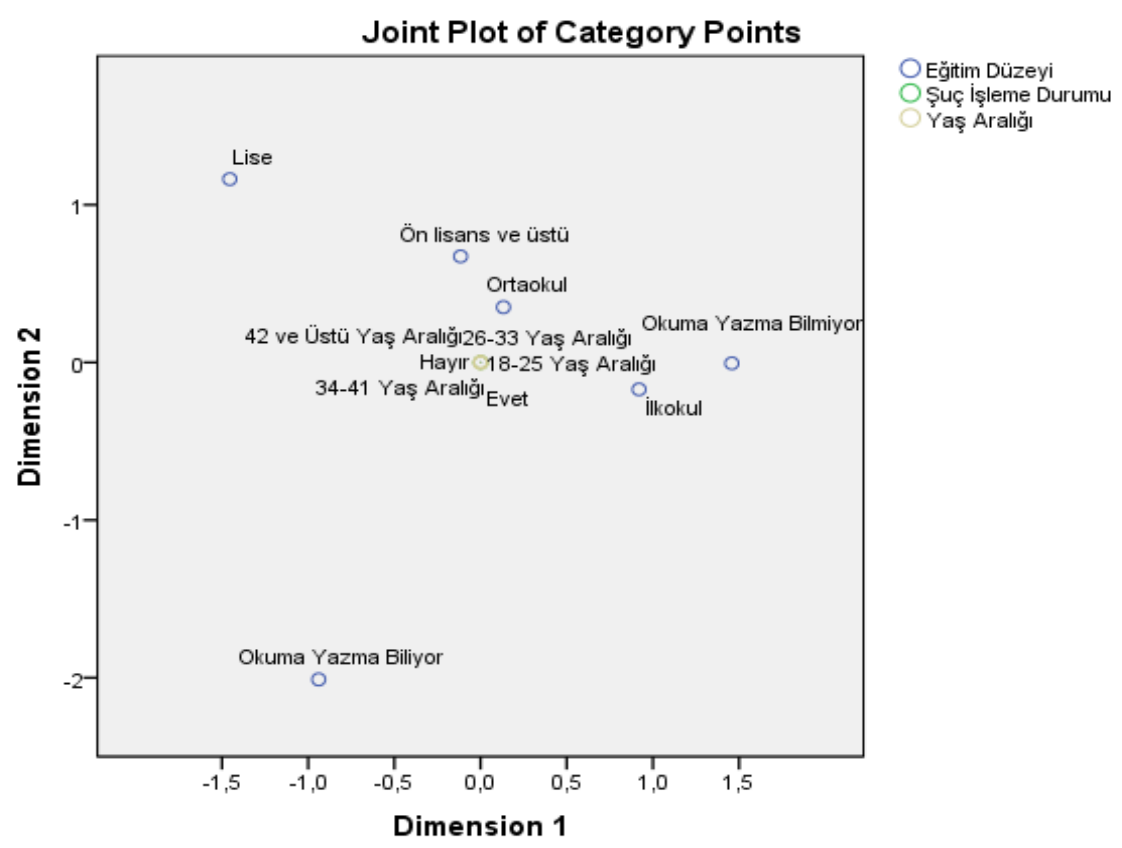

Şekil 2: 2014 yılı Hırsızlık Suçu İşleyen Bireylerin Uyum Grafiği

2014 yılında yapılan araştırma kapsamında tutuklu ve mahkûmlardan elde edilen veriler doğrultusunda 18-25 yaş aralığında bulunan ve ilkokul mezunu olan bireylerin suç işlemeye daha uyumlu olduğu grafiksel açıdan görülmektedir. 2 boyutlu düzlemde boyutların grafiksel açıdan 
değişkenlerin özelliğine göre ayırıma tabi tutmanın önemli olduğu çoklu uyum analizinde her ne kadar grafik okumak verilerin birbirine yakın mesafede olmasından dolayı zor olsa da kategorik verilerde regresyon analizin alternatifi olarak kullanımı yaygınlaşmaktadır.

Tablo 8: Bağımsız Değișkenlere Ait Kategorilerin Koordinatları

\begin{tabular}{llccc}
\hline \multirow{2}{*}{$\begin{array}{c}\text { Sosyo- } \\
\text { demografik } \\
\text { Değişkenler }\end{array}$} & \multicolumn{1}{c}{ Kategoriler } & $\begin{array}{c}\text { Ağırlıklandırılmış } \\
\text { Frekans }\end{array}$ & \multicolumn{2}{c}{$\begin{array}{c}\text { Merkezi } \\
\text { Koordinatlar }\end{array}$} \\
\hline & Okumatlar \\
& Bilmiyor & & $\mathbf{1}$ & $\mathbf{2}$ \\
& Okuma Yazma & 8 & 1,315 &,- 254 \\
& Biliyor & 8 & $-1,491$ & $-1,595$ \\
Eğitim Düzeyi & İlkokul & 8 & 1,053 &,- 836 \\
& Ortaokul & 8 &, 341 &, 621 \\
& Lise & 8 & $-0,810$ & 1,329 \\
& Ön lisans ve üstü & 8 &,- 407 &, 735 \\
Yaş Aralığı & 18-25 Yaş Aralığı & 12 &,- 002 &,- 001 \\
& 26-33 Yaş Aralığı & 12 &, 001 &,- 002 \\
& 34-41 Yaş Aralığı & 12 &, 000 &, 003 \\
Suç İşleme & 42 ve Üstü Yaş & 12 &, 001 &,- 001 \\
Durumu & Aralığı & 24 &, 000 &, 000 \\
\hline & Evet & 24 &, 000 &, 000 \\
\hline
\end{tabular}

2018 y1lında Ankara ilinde tutuklu ve mahkûmlardan elde edilen veriler vasitasıyla hırsızlık suçuna karıştığını beyan eden veya etmeyen bireylerin eğitim düzeyi ve yaş değişkenleri üzerinden uyum durumu aşağıda grafiksel açıdan gösterilmiştir.

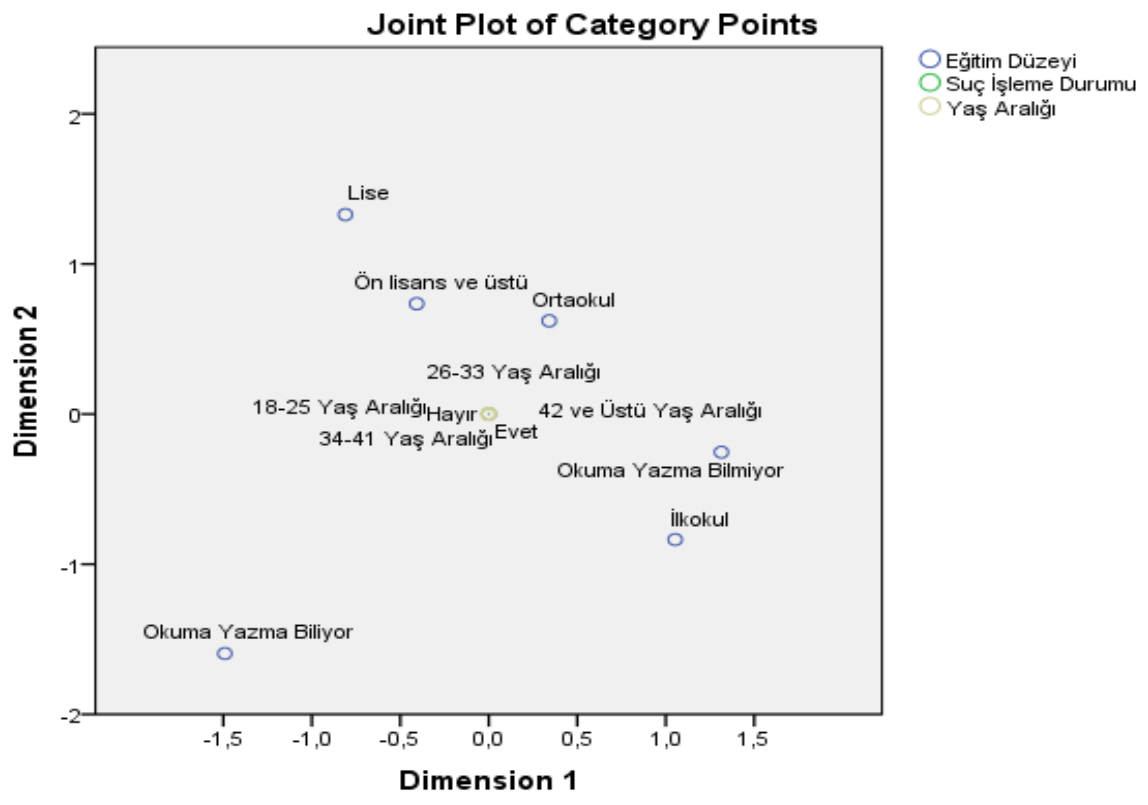

Şekil 3: 2018 yılı Hırsızlık Suçu İşleyen Bireylerin Uyum Grafiği 
2018 yılında Ankara ilinde tutuklu ve mahkûmlardan elde edilen verilere ilişkin çoklu uyum analizi sonuçlarında; okuma-yazma bilmeyen ve ilkokul mezunu bireylerin suça yönelme durumlarının 2014 yılı verilerine göre eğitim durumu açısından benzer sonuçlar ürettiği tespit edilmiştir. Her iki düzlemde sonuçlanı görülen kategorilerin eğitim durumu açısından benzer sonuçlar ürettiği görülmüş, ancak yaş aralığında önem düzeyi tespit edilememiştir. Değişen süreç içerisinde 2014 y1lında etken olduğu tespit edilen eğitim düzeyi olan ilkokul mezunu olma ve okuma yazma bilmeme durumlarının etken olma özelliğini koruduğu anlaş1lırken, yaş aralığının önem düzeyinin etken olmadığ 1 tespit edilmiştir.

Ayrıca literatür bağlamında gelir düzeyi olarak tabir edilen sosyo-ekonomik durum değişkeni majör açıdan önemli tespit edilse dahi alt düzeyleri açısından kategorik bağlamda 2014 yılı verileri özelinde anlamlı sonuç üretmemiştir.

\section{Sonuç}

Sosyo-demografik değişkenler vasıtasıyla suç türlerine özgü betimsel istatistiklerin hazırlanması oldukça popüler bir araştırma alanıdır. Bununla beraber Türkiye özelinde yapılan araştırmaların önemli bir kısmı belirli yıllar üzerinden yapılmış ve etki düzeylerinin sınırlı kaldığı tespit edilmiştir. Bu açıdan örneklem koşullarının aynı kalması kaydıyla elde edilen sonuçların geçerliliğin araştırılmasına yönelik yeteri kadar çalışmanın yapılmadığı tespit edilmiştir. Bu çalışma; 2014 yılında tespit edilen etken değişkenlerin 2018 yılındaki mevcut durumunu araştırmaktadır.

İstatistiksel açıdan bağımlı değişkenlerin diğer değişkenlerin üzerinden açıklanması regresyon analizleriyle yapılmaktadır. Nicel verilerde regresyon analizlerinin model gücü ve etken değişkenlerin düzeyleri daha isabetli sonuçlar üretmektedir. Ancak kategorik verilerde de geliştirilen iterasyon ve algoritmalar sayesinde anlamlı sonuçlar üretilebilmektedir. Yapılan araştırma; Ankara ili özelinde hırsızlık suçunu işlemiş bireylerin sosyo-demografik özelliklerine ilişkin tespitlerin ne ölçüde değiştiğini incelemektedir.

Ceza infaz kurumlarında yer alan erkek tutuklu ve mahkûm bireylere 2014 ile 2018 y1lları arasında uygulanan anketler vasıtasıyla elde edilen veriler 6 temel değişken üzerinden sınıflandırılmış, akabinde suç kategorilerine göre anlamlılık içeren değişkenler belirlenerek, değişimleri ikincil veri tekniğiyle anlaşılmaya çalışılmıştır. Analiz sonuçları değerlendirildiğinde ilkokul düzeyinde eğitim düzeyine sahip olanların hırsılılı suçunu işleme riski 17,6 kat artarken; ortaokul düzeyinde eğitim durumuna sahip bireylerin ise hırsızlı suçunu işleme riski ise 8,5 kat artmaktadir.

2018 y1lında tutuklu ve mahkûmlardan elde edilen verilere ilişkin çoklu uyum analizi sonuçlarında ise; okuma-yazma bilmeme ve ilkokul mezunu bireylerin suça yönelme durumları 2014 yılı verileriyle benzer sonuçlar üretmiştir. Ancak yaş aralığı değişkeni, öne çıkan başlık olarak tespit edilememiştir.

Yapılan çalışmanın 2014 ile 2018 yıllarına ilişkin değişim trendlerini kesikli veriler üzerinden araştırması nedeniyle özgün olduğu değerlendirilmektedir. Eğitim düzeyi değişkeninin 2014 ile 2018 yılları arasında etken değişken olma özelliğini koruduğu tespit edilmiştir. Araştırmaların benzer yöntemler ile mikro ölçekte uygulanması suçlara ilişkin profil değişiminin daha sağlıklı anlaşılmasına katkı sağlayabilir.

\section{Kaynakça}

Aytaç M., Aytaç, S. ve Bayram, N., (2007). Suç Türlerini Etkileyen Faktörlerin İstatistiksel Analizi, 8. Türkiye Ekonometri ve İstatistik Sempozyumu, İnönüÜniversitesi, Malatya, 2425 Mayss.

Turkish Studies - Social, 15(3) 
Hırsızlık Suçuna Neden Olan Sosyo-Demografik Değişkenlerin Yıllara Göre Değişiminin... 1031

Becker, Gary S., (1968). Crime and Punishment: An Economic Approach, Journal of Political Economy, 76(2), pp. 169-217.

Buonanno, P., and Montolio, D. (2008). Identifying the Socio-Economic And Demographic Determinants of Crime Across Spanish Provinces, International Review of law and Economics, 28(2), 89-97.

Ehrlich, I. (1973). "Participation In Illegitimate Activities: A Theoretical And Empirical Investigation", J Political Econ 81, 521-565.

Eide, Erling; Rubin, Paul H. and Shepherd, Joanna.M., (2006), "Economics of Crime". Now Publishers Inc.

Elliott, C., \& Ellingworth, D. (1998). "Exploring the Relationship between Unemployment and Property Crime". Applied Economics Letters, 5(8), 527-530.

Entorf, H., \& Spengler, H. (2000). Socioeconomic and Demographic Factors of crime in Germany. Evidence from panel data of the German States. International Review of Law and Economics, 20(1), 75-106.

Erdoğan, S., Yalçın, M., \& Dereli, M. A. (2013). Exploratory Spatial Analysis of Crimes against Property in Turkey. Crime, Law And Social Change, 59(1), 63-78.

Neuman, W. L. (2014). Toplumsal Araştırma Yöntemleri, Yayınodası, 7. Baskı, Ankara.

Özdamar, K. (2010). Paket Programlarla Ístatiksel Veri Analizi 2, Kaan Kitabevi, 7. Bask1, Ankara.

tuik.gov.tr,(2020).KonularınaGöreİstatistikler,http://www.tuik.gov.tr/PreTablo.do?alt_id=1059, (ErişimTarihi: 11.01.2020).

Tüzüntürk, S. (2009). Çok Boyutlu Ölçekleme Analizi: Suç İstatistikleri Üzerine Bir Uygulama, Uludağ Üniversitesi İktisadi İdari Bilimler Dergisi, 28 (2), s.71-91.

Yorulmaz, Ö. Y., \&Yakut, S. G., (2017). Türkiye'de Suç Oranını Etkileyen Sosyo ekonomik Faktörlerin İncelenmesi: Path Analizine Dayanıklı Yaklaşım. Marmara Üniversitesi Iktisadi ve Ídari Bilimler Dergisi, 2017(1), 307-322. 
T.C.

ADALET BAKANLIĞI

Ceza ve Tevkifevleri Genel Müdürlügü

Sayı : 57292265-204.06.03-E.77/16653

$27 / 01 / 2020$

Konu : Makalenin Yaymlanması Talebi

Sayın Aykut CALIȘKAN

Esentepe Mah. Şehit Oktay Altuntaş

Cad. No: 6/1 Merkez/BAYBURT

Ilgi a)Hacettepe Öniversitesi Fen Bilimleri Enstitüsüne ait 03/04/2018 tarihli ve 3154132-010.99/1702 saylı yazl.

b)25/02/2014 tarihli ve 40843807-1009-578 sayll yaz.

c) $05 / 03 / 2014$ tarihli ve $57292265-204.06 .03-\mathrm{E}, 442 / 38474$ saylı yazımız.

d)02/05/201 8 tarihli we 57292265-204.06.03-E.695/60666 sayılı yazımı.

e)2001/2020 tarihli dilekçeniz.

Ilgi (a) ve (b) sayılı yazılara istinaden, Hacettepe Üniversitesi Adli Bilimler Anabilim Dalı Doktora Öğrencisi olarak "Kişı̇lik Kavramı hle Suçhu Davranış thişkisinin Açıklanması: Malvariığına Karşı Suçlar Orneğinde" ve "Rutin Aktiviteler Teorisi Kapsamunda Mala Zarar Verme Suçu ile Ilgili Mekan Olgusunun Sasyal Faktoriler Bağlamunda Analiz Edilmesi" komulu araştırmalannıza, ilgi (c) ve (d) sayılı yazılanmızla izin verilmiş olup, "Hırsılık Suçuna Neden Olan Sosyo-Demografik Değişkenlerin Değişim Durumlannı Incelenmesi" başhığı altında yeni bir çalışma hazıt anmış olup, adı geçen makalenin yayınlanması talebini içeren ilgi (e) sayıl dilekçeniz incelendi.

Ekte yer alan makalenin yaynlanma talebi uygun görülmûştür.

Bilgilerinizi rica ederim.

Namik Kemal VAROL

Hâkim

Bakan a.

Genel Müdür Yardumeısı 